\title{
Persistent singultus as presenting symptom of syringobulbia
}

\author{
Balasubramanyam Shankar, ${ }^{1}$ Ramakrishna Narayanan, ${ }^{1}$ \\ Samir Mustaffa Paruthikunnan, ${ }^{1,2}$ Chaitanya Dattatray Kulkarni ${ }^{1}$
}

Department of

Radiodiagnosis, Kasturba Medical College, Manipal University, Manipal, Karnataka, India

${ }^{2}$ Department of Radiology, Kasturba Medical College, Manipal University, Manipal, Karnataka, India

\section{Correspondence to}

Dr Balasubramanyam Shankar, balabhaimbbs@gmail.com

Accepted 13 June 2014
CrossMark

To cite: Shankar B,
Narayanan R,
Paruthikunnan S M, et al.
BMJ Case Rep Published
online: [please include Day
Month Year] doi:10.1136/
bcr-2014-205314

\section{DESCRIPTION}

A 22-year-old man presented with persistent hiccups (singultus) since 15 days with giddiness, imbalance while walking and heaviness in the right upper limb since 10 days. On clinical examination the patient had left ataxia with reduced sensation to pinprick over right C5-C7 segments. The patient was suspected to have a neurogenic cause of singultus hence was referred for MRI of the brain and spine.

MRI demonstrated syringobulbia as a slit-like hyperintensity on $\mathrm{T} 2$-weighted image (figure $1 \mathrm{~A}, \mathrm{~B}$ ) in the right dorsal aspect of the medulla which suppressed on fluid attenuated inversion recovery (figure 1C, D). MRI of the cervical and dorsal spine (figure 2) demonstrated syringomyelia from the C2-D2 level. Peg-like cerebellar tonsils displaced into the upper cervical canal through the foramen magnum (figure 2) suggestive of a Chiari I malformation.
Acute singultus (hiccups) is usually a benign transient phenomenon usually caused by overdistension of the stomach, chemical stimulation (such as alcohol) or sudden changes of gastrointestinal temperatures. It involves repeated myoclonic, synchronous, involuntary contractions of the diaphragm and inspiratory intercostal muscles associated with an upper airway closure causing a peculiar sound.

Hiccups are classified according to their duration: acute hiccups that last up to $48 \mathrm{~h}$, persistent hiccups that last for over $48 \mathrm{~h}$ and intractable hiccups are defined as hiccups that last more than 1 month. $^{2}$

Persistent and intractable singultus may cause severe discomfort, decreased physical strength and depression if left untreated. Persistent and intractable singultus may indicate an organic disorder and should be investigated based on history and physical examination with imaging. 


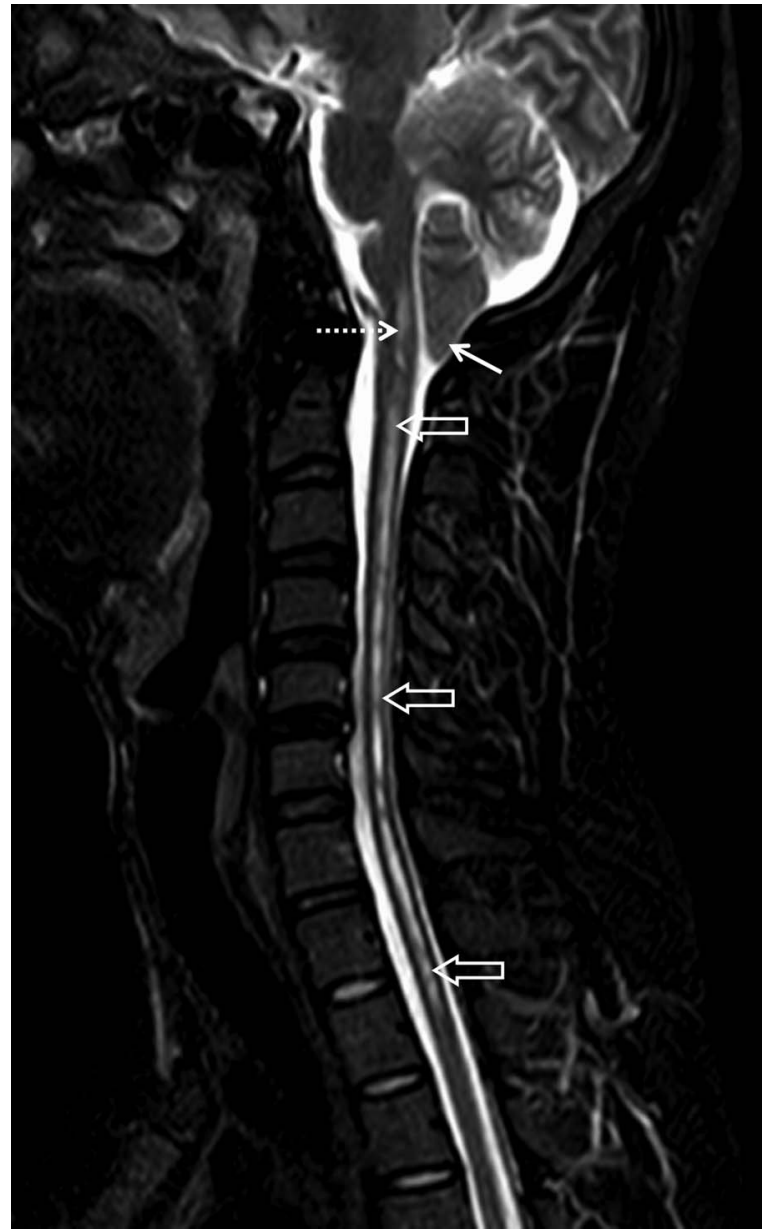

Figure 2 Sagittal short tau inversion recovery images of cervicodorsal spine demonstrating tonsillar herniation (white arrow) into the upper cervical canal, syringobulbia seen as hyperintensity in the medulla (dashed arrow) and syringomyelia of the cord from extending from C2-D2 level.
Neurogenic causes of persistent or intractable singultus include structural or functional disorders of the medulla (involving the region of vagal nuclei and nucleus tractus solitarius) and of the afferent or efferent nerves to the respiratory muscles. ${ }^{3}$ Structural lesions of the medulla such as infarction in the territory of the posterior inferior cerebellar artery, tumour, tuberculoma, abscess, syrinx, haematoma and demyelination can cause persistent singultus. ${ }^{3}$ MRI plays an important role in the evaluation of persistent singultus and diagnosis of brainstem lesions of which syringobulbia due to the Chiari I malformation is a treatable cause.

In our case the cause of persistent singultus can be attributed to the syringobulbia due to Chiari I malformation. The patient underwent foramen magnum decompression and his symptoms were alleviated postsurgery.

\section{Learning points}

- In persistent or intractable singultus (hiccups), a brainstem lesion should be suspected, although the incidence is low.

- MRI plays an important role in the evaluation of persistent singultus and diagnosis of brainstem lesions.

- Syringobulbia due to Chiari I malformation represents a surgically treatable cause of intractable or persistent singultus.

\section{Competing interests None.}

Patient consent Obtained.

Provenance and peer review Not commissioned; externally peer reviewed.

\section{REFERENCES}

1 Marsot-Dupuch K1, Bousson V, Cabane J, et al. Intractable hiccups: the role of cerebral MR in cases without systemic cause. AJNR Am J Neuroradiol 1995;16:2093-100.

2 Marinella MA. Diagnosis and management of hiccups in the patient with advanced cancer. J Support Oncol 2009;7:122-7, 130.

3 Howard RS. Persistent hiccups. BMJ 1992;305:1237-8.

Copyright 2014 BMJ Publishing Group. All rights reserved. For permission to reuse any of this content visit http://group.bmi.com/group/rights-licensing/permissions.

BMJ Case Report Fellows may re-use this article for personal use and teaching without any further permission.

Become a Fellow of BMJ Case Reports today and you can:

- Submit as many cases as you like

- Enjoy fast sympathetic peer review and rapid publication of accepted articles

- Access all the published articles

- Re-use any of the published material for personal use and teaching without further permission

For information on Institutional Fellowships contact consortiasales@bmjgroup.com

Visit casereports.bmj.com for more articles like this and to become a Fellow 